University of Nebraska - Lincoln

DigitalCommons@University of Nebraska - Lincoln A SUBOSCINE PASSERINE SPECIES

Daniel Leger

University of Nebraska-Lincoln, dleger1@unl.edu

Follow this and additional works at: https://digitalcommons.unl.edu/psychfacpub

Part of the Psychiatry and Psychology Commons

Leger, Daniel, "FIRST DOCUMENTATION OF COMBINATORIAL SONG SYNTAX IN A SUBOSCINE PASSERINE SPECIES" (2005). Faculty Publications, Department of Psychology. 476.

https://digitalcommons.unl.edu/psychfacpub/476

This Article is brought to you for free and open access by the Psychology, Department of at DigitalCommons@University of Nebraska - Lincoln. It has been accepted for inclusion in Faculty Publications, Department of Psychology by an authorized administrator of DigitalCommons@University of Nebraska - Lincoln. 


\title{
FIRST DOCUMENTATION OF COMBINATORIAL SONG SYNTAX IN A SUBOSCINE PASSERINE SPECIES
}

\author{
DANIEL W. LEGER ${ }^{1}$ \\ Department of Psychology and Nebraska Behavioral Biology Group, University of Nebraska, \\ Lincoln, NE 68588-0308
}

\begin{abstract}
Birds with songs having two or more acoustically distinct elements can arrange them either rigidly (i.e., in the same sequence) or flexibly. Flexible song syntax can be achieved either by varying the number of repetitions of elements or by combining elements in different ways. Combinatorial syntax has been documented only in the songs of oscine passerines and in one nonpasserine, but not in the suboscine passerines. Dawn and day songs of a tyrant flycatcher, the Flammulated Attila (Attila flammulatus), were recorded in Costa Rica. Flexible syntax was noted in both dawn and day song. Attilas not only varied the number of repetitions of their song elements but also combined elements in various ways. This appears to be the first reported case of combinatorial song syntax in a suboscine species.
\end{abstract}

Key words: Attila, song, suboscine, syntax, tyrant flycatcher.

\section{Primer Registro de Sintaxis Canora Combinatoria en una Especie Paserina Suboscine}

Resumen. Las aves canoras que poseen dos o más elementos acústicos distintivos pueden acomodarlos ya sea de modo rígido (i.e., en la misma secuencia) o de modo flexible. La sintaxis flexible de cantos puede alcanzarse ya sea variando el número de repeticiones de los elementos o combinando los elementos de diferentes modos. La sintaxis combinatoria ha sido documentada sólo en los cantos de paserinos oscines y en un ave no paserina, pero no en paserinos suboscines. Los cantos del amanecer y diurnos de un tiránido atrapamoscas, Attila flammulatus, fueron registrados en Costa Rica. Encontramos evidencia de sintaxis flexible en cantos del amanecer y diurnos. A. flammulatus no sólo varió el número de repeticiones de su canto, sino que también combinó elementos de varios modos. Este parece ser el primer registro de sintaxis canora combinatoria en una especie suboscine.

\section{INTRODUCTION}

Bird song exhibits organization at all levels of its expression, ranging from the most basic units of sound production to repertoires of songs (Nowicki and Podos 1993). By "organization" I am referring to the predictability with which song elements or song types follow others. The most basic level of song organization consists of notes, which are usually defined as continuous tracings on a sound spectrogram. If notes consistently are associated with other notes, they form a syllable, and syllables or notes may be combined to form a phrase. A song consists of one or more different notes, syllables, or phrases that may be combined with one another in various ways to make different song types. Finally, a song type may be repeated several times before switching to a different song type, or at the

Manuscript received 10 March 2005; accepted 1 August 2005 .

${ }^{1}$ E-mail: dleger1@unl.edu other extreme, the singer may change song types each time it sings a song.

Notes, syllables, and phrases, which I generically will call "song elements," may be ordered relative to each other. Among bird species having more than one type of song element, the sequencing of the elements can be either rigid or flexible. In rigid syntax, transitions from one element to the next are perfectly predictable. Some variability from one song to the next can occur even with rigid syntax, but it comes about either by terminating the song at various points, or by shifting the frequencies of the notes, both of which occur in the Nightingale Wren (Microcerculus philomela, Leger et al. 2000). Rigid syntax can occur even in species that have song repertoires, provided that each song type has different elements and that element sequencing is invariant (Hailman 1989).

Flexible syntax is present whenever uncertainty exists in the sequencing of song elements. Stated differently, there may be points in the song where the singer has a "choice" as to 
which element will occur next. Choices can be of two types. First, song elements may be repeated a variable number of times before moving on to the next element. For example, in one song the bird may sing AAABBCC but in the next it may sing $\mathrm{ABCC}$, where letters refer to acoustically distinct song elements. This form of flexible syntax is similar to rigid syntax in that the same sequence of elements is maintained from one song to the next.

Second, flexibility may be achieved by combining elements in various ways. Such combinatorial syntax (sensu Hailman 1989) can be achieved through different processes. For example, the Black-capped Chickadee (Poecile atricapillus) employs combinatorial syntax in its call system and does so by omitting one or more of the elements. The sequencing is always in the order $\mathrm{ABCD}$, but one or more of the elements may be omitted. Black-capped Chickadees also vary the number of repetitions of the elements (Hailman and Ficken 1986). Similar observations have been made on the Mountain Chickadee (P. gambeli, Bloomfield et al. 2004) and the Mexican Chickadee ( $P$. sclateri, Ficken et al. 1994), among others.

Another method of combinatorial syntax occurs when the bird has a pool of song elements in its repertoire that can be strung together in different combinations or permutations. For example, Winter Wren (Troglodytes troglodytes) song phrases, which can be several seconds in duration and consist of many notes, are inserted in various positions in the song, resulting in very large song repertoires (Kroodsma 1980). Lengthy and combinatorially complex songs also occur in several other species, such as the European Starling (Sturnus vulgaris, AdretHausberger and Jenkins 1988).

Some elements are more likely than others to occupy the first position in a song, while other elements tend to occur in middle or terminal positions (Catchpole 1976, Zann 1993). Further, some sequenced pairs of elements are more common than others. These tendencies mean that the observed number of unique song types is much lower than the number that could be produced if the available elements were combined in an unbiased manner. For example, Warbling Vireo (Vireo gilvus) song begins with one of a small number of notes in the bird's repertoire, followed by various combinations of other notes, some of which are common while others are rare. The large number of song types that result is still only a fraction of the total possible number (Howes-Jones 1985). Ficken and Popp (1992) have described a similar arrangement in the gargle vocalization of Black-capped Chickadees.

In some cases combinatorial syntax is achieved by repeating the song without the normal intersong interval. For example, Bluethroated Hummingbird (Lampornis clemenciae) type 1 song consists of five units, designated AE. After singing the $\mathrm{E}$ unit the bird usually terminates the song but sometimes immediately repeats units $\mathrm{B}, \mathrm{C}, \mathrm{D}$, and $\mathrm{E}$. In this case, the repeated units are accompanied by omission of the A unit (Ficken et al. 2000), a phenomenon also known to occur in Wood Thrush (Hylocichla mustelina) song (Dobson and Lemon 1979).

Combinatorial syntax has been referred to as a procedural hierarchy (Todt and Hultsch 1998), branching (Dawkins 1976, Gil and Slater 2000), and as path organization (Ficken et al. 2000). All the avian examples of combinatorial syntax would be classified as "finite state grammars," and although some of them are similar to the "phrase structure grammar" found in human language, the similarity is thought to be only superficial (Fitch and Hauser 2004). Examples of combinatorial syntax are fairly common among oscine passerines, but seem to be extremely rare in other taxa (but see Ficken et al. 2000).

In this paper, I describe the first case of combinatorial syntax in a suboscine passerine, the Flammulated Attila (Attila flammulatus), a Neotropical tyrant flycatcher. This species varies its repetition of song elements, but also combines its song elements in varied ways. Attila songs are longer than those of most other tyrant flycatchers. Attilas sing two acoustically distinct song types, one of which is sung primarily at dawn and dusk and the other primarily during the day (Skutch 1971). Leger and Mountjoy (2003) described geographic variation in the vocalizations and morphology of Bright-rumped Attilas (A. spadiceus, sensu AOU 1998) and concluded that the differences between birds in the northern (Panama to Mexico) and the southern (South America) parts of the range were great enough to justify recognition of the northern birds as a distinct species, A. flammulatus. 


\section{METHODS}

I recorded songs at the La Selva Biological Station $\left(10^{\circ} 26^{\prime} \mathrm{N}, 83^{\circ} 59^{\prime} \mathrm{W}\right)$ in northeastern Costa Rica during March 1998 and March 2000, and at the Las Cruces Biological Station $\left(8^{\circ} 47^{\prime} \mathrm{N}\right.$, $82^{\circ} 57^{\prime} \mathrm{W}$ ) in southwestern Costa Rica in March 2002. I also analyzed recordings made by D. J. Mountjoy at La Selva in 2000.

The 1998 recordings were made with a Sony TCM5000EV cassette recorder and a Sennheiser ME67/K6 microphone. The recordings in 2000 were made with Tascam DA-P1 and Sony TCDD8 DAT recorders, both of which were equipped with Sennheiser ME67/K6 microphones. The 2002 recordings were made with the Tascam recorder and a Sennheiser MKH70 microphone. Recordings used for spectrographic analyses will be deposited at the Borror Laboratory of Bioacoustics at Ohio State University.

Recordings were digitized (16-bit, $22 \mathrm{kHz}$ ) using Canary 1.2.4 software (Cornell Laboratory of Ornithology, Ithaca, New York) on Macintosh computers. Spectrograms were made of all recordings that were sufficiently clear using $\mathrm{Ca}-$ nary 1.2.4 (frame length: 512 points, filter: 175 $\mathrm{Hz}$, Hamming window, with grid resolutions of $11.6 \mathrm{~ms}$ and $43.07 \mathrm{~Hz}$ ). My assistants and I measured the duration and the lowest and highest frequencies of the main phrase of each song (Fig. 1 and 3), and noted the types of elements present and their order. We also measured the following intersong interval. We assessed interrater reliabilities by having each pair of researchers independently measure a set of 100 songs sampled from throughout the full set. Our independent measurements differed by less than $4 \%$ on all of the temporal and spectral measures.

Quantitative data are based on spectrograms of 22 bouts of dawn song and 24 bouts of day song. The dawn song bouts had an average of 22 songs and were about three minutes in duration; day song bouts were shorter (14 songs and 2.5 minutes, on average). Birds were not banded, so they were "identified" by their locations. I refrained from using more than one bout of a song type from a location, but in several cases I used a bout of dawn song and a bout of day song from the same area. I estimate that the 46 analyzed bouts came from at least 28 individuals.

Another 70 bouts of singing were recorded (usually in the background while recording other species); these were not strong enough to permit reliable spectrographic analyses, but were adequate to describe diel patterns of singing.

To avoid the statistical problems that might arise from treating songs from the same bout as independent data points, I calculated the mean for each variable for each bout before using these values to compute statistics for the entire dataset. Values reported are means $( \pm \mathrm{SD})$.

\section{RESULTS}

\section{SINGING BEHAVIOR}

The earliest singing began at 05:15 and the latest occurred at 17:42 (CST). Singing attilas were usually stationary and although I observed birds change perches between songs by making short flights, I never observed birds singing in flight. Farabaugh (1982) included the Bright-rumped Attila in a list of duetting species in Panama, but I never observed duets at my study sites. Because attilas often sing in dense canopy conditions, it is usually difficult to see them; nevertheless, based on cases when I saw attilas singing, I verified that birds sang solo.

Because attilas sing two acoustically distinct song types (dawn and day songs) and because singing is fairly common among females in tropical species (Slater and Mann 2004), I tested the hypothesis that males and females might be responsible for the two song types. I eliminated this hypothesis simply by recording several birds as they transitioned from dawn song to day song, or vice versa. Attilas are sexually monomorphic, so I was not able to ascertain the sex of singing birds; however, if both sexes sing, as was reported by Skutch (1971), they must do so in the same way since there was no indication of subtypes within either song category.

Dawn song was the most common song type early in the morning and again at dusk. Of the 37 song bouts recorded prior to 06:00, 33 (89\%) were dawn songs. Between 06:00 and 07:00, dawn song bouts accounted for 12 of 28 recordings (43\%). Singing was far less common after about 07:00, with only 35 bouts (dawn and day combined) recorded between 07:00 and 16:00; 11 of these bouts $(31 \%)$ were dawn songs. Finally, 10 of 16 bouts (63\%) recorded after 16:00 were dawn songs.

Birds spent more of their time producing song when singing dawn songs than when singing day songs. The mean intersong interval for dawn 

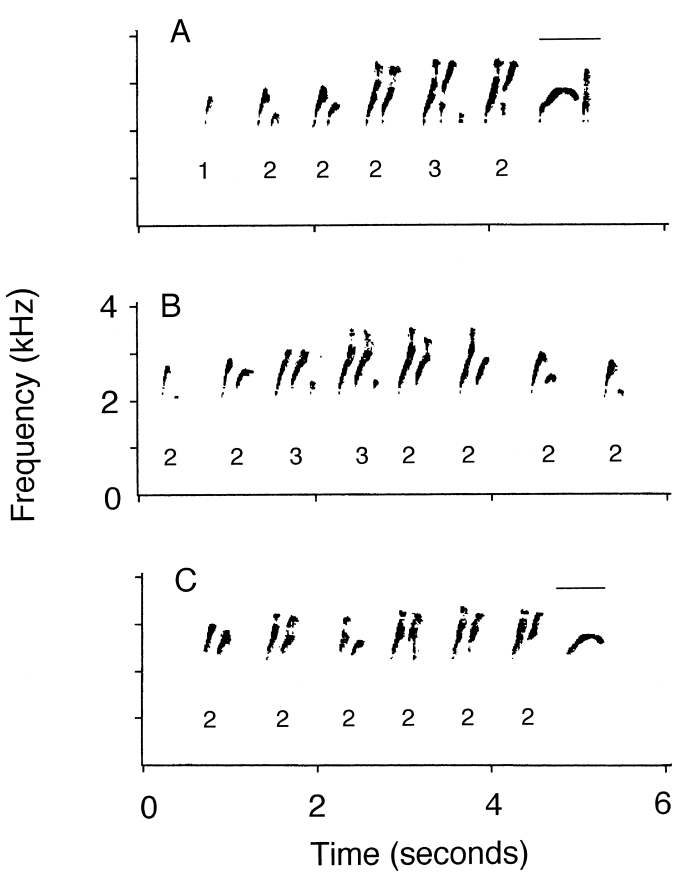

FIGURE 1. Examples of Flammulated Attila dawn song recorded from three birds at Las Cruces, Costa Rica. Examples of 1-, 2-, and 3-note syllables of the main phrase are indicated with numerals beneath the syllables. Song A contains both parts of the terminal phrase ("whew" and "whit," beneath the horizontal line), B lacks a terminal phrase entirely, and $\mathrm{C}$ has only the "whew" note of the terminal phrase (beneath the horizontal line)

songs was $3.3 \pm 2.0 \mathrm{sec}$, which was significantly shorter than the mean intersong interval for day songs $\left(9.2 \pm 6.6 \mathrm{sec}, t_{40}=3.9, P<0.01\right)$. Performance time is the percentage of time in which the bird is actually producing song during a bout. Mean performance time for dawn songs was $67 \%$, which was significantly greater than the mean performance time for day songs (23\%; $\left.t_{39}=8.9, P<0.001\right)$.

\section{DAWN SONG}

Dawn song consists of a main phrase and an optional terminal phrase (Fig. 1). The main phrase consisted of up to four syllable types, which are defined by the number of their constituent notes (1, 2, 3, and 4 notes). On average, the main phrase duration was $4.7 \pm 1.5 \mathrm{sec}$ and its frequency ranged from $2.1 \pm 0.1 \mathrm{kHz}$ to 3.2 $\pm 0.1 \mathrm{kHz}$ (mean lowest and highest frequencies). The detailed form of the notes of a syllable type were variable, both within and among birds. For example, the generally upward slope of the notes was variable, as was the total frequency range of a note. Since there were no obvious discontinuities in these variables, I did not attempt any finer-grained classification of syllables.

Dawn song has a crescendo quality, generally rising in intensity from beginning to end. This is especially true for songs that began with 1note syllables, which are quite soft. Two-note syllables were louder than 1-note syllables and the frequency range of both notes generally increased farther into the song (Fig. 1A). However, attilas sometimes reduced the amplitude of successive syllables toward the end of a song (Fig. 1B).

The terminal phrase of dawn songs consisted of one or two note types, as shown in Figure 1. The most common terminal note resembled a shallow, inverted "u." Approximately $71 \%$ of all songs (340 of 476) had this "whew" note. Of the 340 songs with this note, $211(62 \%)$ were immediately followed by a very brief "whit" note, which invariably ended the song (Fig. 1A). Terminal phrases did not occur without the main phrase, and a "whit" note never occurred without the "whew" note preceding it.

Twenty-one of the 22 dawn song bouts had at least one song with 1-note syllables. All 22 bouts had 2-note syllables present in at least one song, and 12 bouts had 3-note syllables. Only one bout contained a 4-note syllable, and it occurred once in each of two successive songs. With regard to the terminal phrase, all 22 birds used the "whew" note and 17 used the "whewwhit" combination at least once.

Variable repetition of song elements. Singing birds varied the number of repetitions of their syllables. The mean number of 1-note, 2-note, and 3-note syllables was $1.4,4.4$, and 4.3 , respectively, based on those songs that had at least one instance of that syllable. The ranges were 1-4 for 1-note syllables, 1-14 for 2-note syllables, and 1-11 for 3-note syllables.

Omissions of song elements. If a bird was known to have a song element in its repertoire (as judged by its appearance in at least one of its songs) then that element could be regarded as having been omitted if it did not appear in a particular song. For example, of the 12 birds that were known to have 3-note syllables in their repertoires, the 3-note syllable was missing in 51\% of their songs (87 of 171 songs). As noted 
above, all birds sang the "whew" note at least once, but it was omitted from $30 \%$ of all songs. Finally, of the 17 birds that sang the "whit" note at least once, 82 of their 297 songs that had "whew" did not follow it with the "whit" note. Summarizing, although attila dawn songs have only five common elements, birds often omitted one or more of them in any given song.

Recombination of song elements. Dawn songs usually commenced with 1-note syllables (345 of 484 songs, or $71 \%$ ), but 139 songs began with a 2-note syllable (29\%). Because 1-note syllables are usually sung at low intensity, it is possible that I may have overlooked some songs that began with 1-note syllables, and misattributed them as beginning with 2-note syllables. This seems unlikely, however, since I observed 1-note syllables in 21 of 22 bouts (the one exception was a brief recording that had only two songs), so the recording conditions were clearly adequate to detect 1-note syllables. Similarly, the third note of 3-note syllables tended to be briefer and not as loud as the first two notes, so there is a possibility that a 3-note syllable may have been mistaken for a 2-note syllable, but this also seems unlikely because 3-note syllables were apparent even in some of the recordings that were judged to be too soft for spectrographic analysis.

Of the 345 songs that began with a 1-note syllable, nearly all (337 or $98 \%$ ) switched to 2note syllables. The eight songs that began with 1-note syllables that did not go on to 2-note syllables are probably best regarded as aborted songs and were not analyzed further. In no case did a bird switch directly from 1-note to 3-note syllables or to a terminal phrase. Stated differently, all 476 nonaborted songs contained at least one 2-note syllable, making this syllable the backbone of attila dawn song.

After singing several repetitions of the 2-note syllable, attilas ended the song, either with silence $(n=132)$ or with a terminal phrase $(n=$ 281). However, 84 songs (25\%) transitioned from 2-note syllables to 3-note syllables.

Attilas sometimes used a syllable at two places in the song. The most common example of this practice involved birds returning to 2-note syllables after singing 3-note syllables. Of the 84 songs that had 3-note syllables, 24 (29\%) switched back to 2-note syllables before terminating. The 1-note syllable sometimes appeared following the 2-note syllable (the sequences 1-

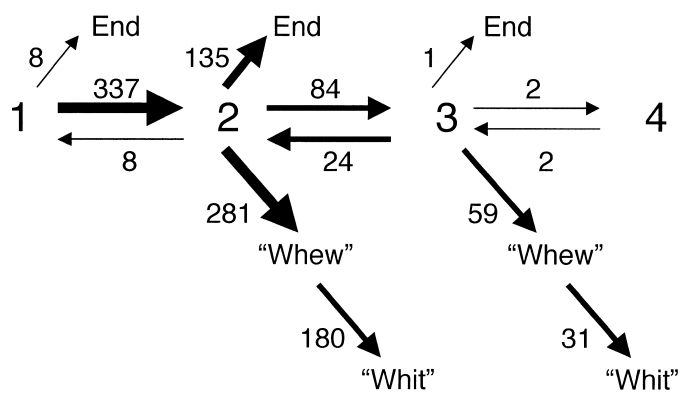

FIGURE 2. Diagram showing the transitions among elements of dawn song of Flammulated Attilas. Songs began with either 1-note syllables $(n=345)$ or with 2-note syllables $(n=139)$. Numbers next to arrows indicate the number of songs that exhibited that branch. "Whew" and "whit" are the two elements of the optional terminal phrase. "End" means that the song ended without a terminal phrase. Width of the arrows is roughly proportional to the frequency of use for the path.

2-1-2 or 2-1-2 occurred in a total of eight songs). The bird that sang a 4-note syllable in two of its songs returned immediately to 3-note syllables. In total, about $7 \%$ of all songs (34 of 484) included one of these forms of recombination.

Combinatorial syntax was apparent in nearly all birds singing dawn song. Nineteen of the 22 bouts of dawn song had songs from at least two categories, and the mean number of categories present in a bout of singing was 4.4. As one would expect, shorter bouts tended to have fewer categories represented, but one bird with only nine recorded songs had nine different categories.

To summarize, the most common sequence in the main phrase of dawn songs was to begin with a few 1-note syllables and then switch to several repetitions of 2-note syllables before ending, either directly or with some version of the terminal phrase. Alternatively, the bird switched from 2-note to 3-note syllables (and sometimes back again) before using one of the ending options. The various "paths" through the dawn song of A. flammulatus are shown in Figure 2.

\section{SEQUENCING OF DAWN SONG TYPES}

Do singing attilas follow a song with another of the same type, or do they switch to something else? For this analysis, I ignored variation in the number of repetitions of a song element, and considered two songs given in sequence to be of 
the same type if they had the same elements arranged in the same order, as Hailman and Ficken (1986) did with chickadees. (Had I treated different repetition numbers as different song types, the number of song types would have been prohibitively large relative to the total number of songs.)

After dropping the four song types that occurred only once in my sample, there were 18 song types present. Therefore, there were 324 possible types of transition, but only 79 of these were observed. In the total sample of dawn songs there were 436 transitions, 176 of which were to the same type $(40 \%)$. Because only 18 of the $324(5.6 \%)$ possible transitions qualified as same-type transitions, only 24.4 cases would be expected to occur in these cells if transitions occurred by chance. Thus, the observed number of same-type transitions $(n=176)$ was far greater than would be expected by chance $\left(\chi^{2}=\right.$ 1008, $P<0.001)$.

Were successive songs likely to begin the same way? To find out, I classified all song transitions as having the same starting element (either 1-note or 2-note) or different starting elements. Successive songs were very likely to begin with the same element $\left(n=316\right.$, or $73 \%, \chi^{2}$ $=44.8, P<0.001)$. However, this analysis included the songs that were of the same exact type. When these songs were omitted, birds were no more likely to follow one song with another that began with the same syllable $(n=$ 140 of 260 , or $54 \%, \chi^{2}<1.0, P>0.05$ ).

A similar picture emerged with respect to song endings. Excluding songs that were of the same exact type, only 79 of the 260 transitions involved the same ending (i.e., silence, "whew" alone, or "whew-whit."). This value did not differ significantly from that expected by chance $\left(\chi^{2}{ }_{4}=7.3, P>0.05\right)$.

In summary, although there was a strong tendency for attilas to follow one dawn song with another of exactly the same type, if the bird did not repeat with the same type then it was apparently a random selection of how to start or end the next song.

\section{DAY SONG}

Day song consists of a main phrase and an optional terminal phrase. The main phrase consisted of a variable number of roughly J-shaped notes. Several variations of the J-note form were observed, some of which are shown in Figure 3.
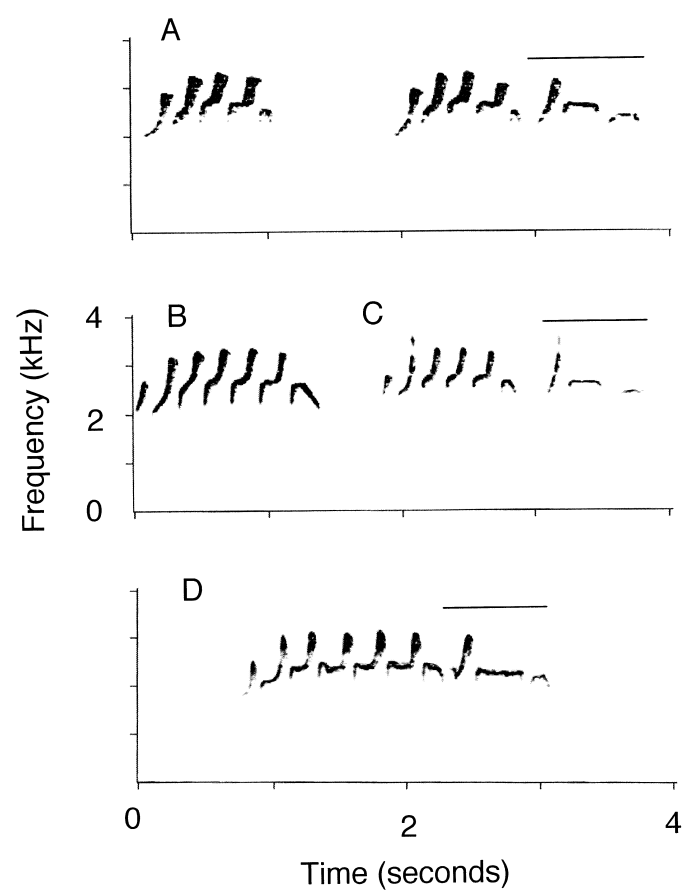

FIGURE 3. Examples of Flammulated Attila day songs: A is two successive songs from one individual (intersong interval shortened), the second of which has a typical terminal phrase; and B, C, and D are from three different individuals. Terminal phrases are the notes beneath the horizontal lines. Note the differences in the structure of the main phrase and terminal phrase notes.

The first note of the main phrase often differed from the others, being briefer and covering a reduced frequency range. The last note was also somewhat different, often being an inverted "U". The main phrases of day songs were 1.6 $\pm 0.6 \mathrm{sec}$ long, and had $8.9 \pm 3.1$ notes. The frequency range of day songs was similar to that of dawn songs, with a mean low frequency of $2.1 \mathrm{kHz}$ and a mean high frequency of $3.2 \mathrm{kHz}$.

Terminal phrases immediately followed 39\% of day songs (134 of 345). The terminal phrase usually consisted of three notes (Fig. 3), but others had from four to six notes. In 28 cases a terminal phrase occurred without being immediately preceded by a song, and in another 28 cases a song was followed by two repetitions of the bird's terminal phrase.

Attilas did not seem to follow a day song with another that ended in the same way. For each song transition I noted the presence or absence of the immediate terminal phrase in the first 
song of the pair and its presence or absence in the following song. I did not include songs that were followed by an isolated terminal phrase. Using the set of transitions $(n=219)$ from the recordings in which the bird sometimes used the terminal phrase and sometimes did not, there was no tendency to follow a song with one of the same type, or to switch to the other type. The observed pattern of transitions was extremely close to what would be expected by chance $\left(\chi^{2}<1.0, P>0.05\right)$.

\section{DISCUSSION}

The Flammulated Attila sings two acoustically distinct song types. Dawn songs have up to six elements, four of which occurred in the main phrase and two others in the terminal phrase. Birds sequenced these elements in flexible but predictable ways. Attilas varied the number of repetitions of dawn song elements before going on to the next element or ending the song. They combined elements in different ways by using two different starting elements and three ways of ending songs. Ignoring variable repetitions of song elements, 22 different patterns were observed at least once. Most birds had four or more patterns present in the recorded sample of their singing. Individual birds that were known to have elements in their repertoire often omitted some of these elements from songs.

Day songs seemed to be less flexible than dawn songs, but birds often failed to give the terminal phrase, sang the terminal phrase without first singing the main phrase, or repeated the terminal phrase. Day songs also varied in the number of repetitions of the most common note of the main phrase.

To my knowledge, these data represent the first demonstration of combinatorial song syntax in a suboscine passerine. Although variable repetition of notes is common in suboscine song (e.g., Zimmer 1999), there appear to be no published cases involving flexible combinations or permutations of song elements. One possible exception involves Zimmer's (1999) description of the loudsong of the Yapacana Antbird (Myrmeczia disjuncta), which consists of two harsh elements separated by a pause in which one or two "pip" notes could be inserted. He reported that birds commonly omitted pip notes from the pause, but the latter may be the female version of the song. His report was not clear as to whether any individual bird gave both versions of the song. Although I lack sufficient material for detailed analysis of A. spadiceus, the South American sister species of $A$. flammulatus, individual birds used different sequences of song elements.

Combinatorial song syntax in attilas is not as extensive as it is in some oscines. Attilas have only six dawn-song elements compared to the dozens that have been reported in many oscines (Lemon and Chatfield 1973). Attilas had only two ways of starting their dawn songs, and they did not recombine elements to nearly the same extent as described in oscines. The only other nonoscine reported to have combinatorial syntax, the Blue-throated Hummingbird, is also limited in its flexibility compared to oscines, and in fact this species exhibits flexibility very similar to that of the Flammulated Attila. Blue-throated Hummingbirds maintain a rigid sequence of song elements, but they sometimes omit one or more of the earlier "units" to begin with a later one. Recombination is limited to beginning the song again without a delay, but when they do so, they drop the first unit. It will be interesting to study song syntax more carefully in other nonoscine species. Other cases of combinatorial syntax likely await discovery, and the means by which it is achieved could be rather different than in the two known cases.

Although this may be the first reported case of combinatorial syntax in suboscine song, suboscines have long been known to vary the sequences of their song types (Borror 1961). For example, Eastern Wood-Pewees (Contopus virens) generally alternate the two song types that they sing at dawn, but this alternation is far from perfect (Smith 1988). Black Phoebes (Sayornis nigricans) also alternate type-1 and type- 2 dawn songs (Smith 1970). Myiarchus flycatchers seem to have a larger repertoire of sounds than most tyrant flycatchers and they sequence them in various ways (Smith and Smith 1996). It is important to note that these cases involve flexible sequencing of whole songs, not flexible sequencing of song elements. Although the songs of many flycatchers are shorter than the syllables sung by many oscines, the intervals following them are significantly longer than the intervals between their constituent notes, and this difference in intervals may be the best way of operationally distinguishing songs from song elements (Isaac and Marler 1963). 
Because all other species that have combinatorial song syntax (including the Blue-throated Hummingbird) are known to learn some features of their song, the discovery of combinatorial song syntax in A. flammulatus could mean that this species may learn some aspects of its song as well. To date, the only suboscine species suspected of song learning is the Three-wattled Bellbird (Cotingidae: Procnias tricarunculata). Snow (1977) concluded that bellbirds improvise and imitate songs. Nonetheless, the flycatchers (Tyrannidae) have never been reported to incorporate learning in any aspect of song production. However, song development has only been studied under controlled laboratory conditions in Willow and Alder Flycatchers (Empidonax traillii and E. alnorum) and Eastern Phoebes (Sayornis phoebe). Their songs were not affected by procedures that are highly disruptive to song development in oscines (Kroodsma 1984, 1985, Kroodsma and Konishi 1991). In addition, a field study of Acadian Flycatchers (E. virescens) revealed no evidence of geographic differences in song, which might result from song learning, although the spatial scale in that study was quite small (Payne and Budde 1979).

Consistent with the possibility of song learning in A. flammulatus, I noted individual differences in note structure. Careful inspection of spectrograms revealed differences among individuals in the acoustic features of their songs. In dawn songs, I found only one bird that sang 4note syllables, and although most birds used the common J-note structure in the main phrase of day songs (Fig. 3A, C), others sang that note differently (Fig. 3B, D). Similarly, most birds used a 3-note terminal phrase following day songs, but others routinely sang 4-, 5-, or 6-note terminal phrases. The second note of the terminal phrase of one bird (Fig. 3D) was significantly longer than that of other attilas at Las Cruces, and it was sung this way in all of its songs. Of course, individual differences in song acoustics do not necessarily mean that the differences are due to learning. Acoustic differences could arise from individual differences in morphology or physiology of the sound production apparatus (Slater et al. 2000). Whether the observed differences in acoustic structure in attila song are due to learning or to song-production mechanism differences awaits further study. Nevertheless, I offer these observations to emphasize that suboscine song may be more vari- able and complex than we have realized, and that the question of whether learning is involved in song ontogeny in this large but under-studied suborder remains largely unanswered.

Although the laboratory studies of song ontogeny in tyrant flycatchers have been technically well done, the number of species that has been studied (three) is very small relative to the 1151 suboscine species (Sibley and Monroe 1990) to which their results are often generalized. Further, these three species are all migrants, breeding in the United States and Canada, but wintering in the tropics. Because only 32 flycatcher species do so (Rappole 1995), and because these three species are restricted to two genera from one subfamily, it may be premature to make generalizations to the rest of the family and suborder. Tropical resident species often differ from related migratory species in important ways (Stutchbury and Morton 2001), and the possibility exists that the tyrant flycatcher species that maintain year-round territories may differ from migratory species in their vocal behavior as well (Morton 1996). Flammulated Attilas are typical of tropical tyrannids in that they maintain year-round territories.

Perhaps because suboscine song is believed to develop normally without learning, descriptions of suboscine song variation have not been as thorough as those on oscine song. Notable recent exceptions are papers by Lovell and Lein (2004) on Alder Flycatchers, and Wiley (2005) on Acadian Flycatchers, both of which reported subtle but significant individual differences in song. Among tropical flycatchers, only one species, the Cocos Flycatcher (Nesotriccus ridgwayi) has been investigated to the extent that quantitative descriptive statistics of its song features have been published (Kroodsma et al. 1987). The absence of such data for other species may imply that little variation exists or that the existing variation is unimportant for the task at hand, which has usually been species identification (Zimmer et al. 2001) or the description of their geographic ranges (Isler et al. 1998).

The presence of distinct dawn and day song forms in the Flammulated Attila also occurs in some other flycatchers and in many oscines (Staicer et al. 1996). Among flycatchers, Smith (1966) reported that kingbirds (Tyrannus) sing a distinctive song around sunrise (but also occasionally during the day). Dawn song also occurs in phoebes (Smith 1970), Myiarchus flycatchers 
(Smith and Smith 1996), and others (Parker 1984, Zimmer and Whittaker 2000). In contrast, the presence of a distinct dawn song is not apparent in the descriptions of some other flycatcher species, even those for which careful descriptions have been provided (Kroodsma et al. 1987). To my knowledge, the presence of a distinct dawn- and day-song repertoire has not been subjected to phylogenetic analysis.

In oscines, the wood warblers (Parulinae) often have two distinct song forms, with one being more common at dawn and dusk, and the other during the day (Morse 1989, Staicer 1989, Bolsinger 2000). When wood warblers use dawn song during the day, the context is generally one of male-male conflict. Singing attilas were rarely visible, but their use of dawn songs during the day did not seem to occur during conflicts. Attilas were often stationary while singing and other singing attilas were usually in the distance. Thus, I cannot readily account for their occasional use of dawn songs during the day.

In summary, the Flammulated Attila exhibits combinatorial song syntax, especially in its dawn song. This appears to be the first reported case involving a suboscine passerine and only the second case involving nonoscines. Attilas achieve combinatorial syntax using the same mechanisms found in oscines, but attila song is not as flexible as that of most oscines.

\section{ACKNOWLEDGMENTS}

I thank the Organization for Tropical Studies for the opportunity to work at La Selva and Las Cruces, and their staffs for their hospitality. The Nebraska Behavioral Biology Group provided funding for this work. Jim Mountjoy kindly made his recordings available for analysis and Amy De Pierre and Derek Lackaff assisted with spectrographic analyses. Cody Arenz, Jim Mountjoy, Christopher Sturdy, and an anonymous reviewer contributed many helpful suggestions on earlier versions of the manuscript.

\section{LITERATURE CITED}

Adret-Hausberger, M., And P. F. Jenkins. 1988. Complex organisation of the warbling song in the European Starling Sturnus vulgaris. Behaviour 107:138-156.

AMERICAN ORNITHOLOGISTS' UNION. 1998. Checklist of North American birds. 7th ed. American Ornithologists' Union, Washington, DC.

Bloomfield, L. L., I. Charrier, and C. B. Sturdy. 2004. Note types and coding in parid vocalizations. II: The chick-a-dee call of the Mountain Chickadee (Poecile gambeli). Canadian Journal of Zoology 82:780-793.
Bolsinger, J. S. 2000. Use of two song categories by Golden-cheeked Warblers. Condor 102:539-552.

BorRoR, D. J. 1961. Intraspecific variation in passerine bird songs. Wilson Bulletin 73:57-78.

Catchpole, C. K. 1976. Temporal and sequential organisation of song in the Sedge Warbler (Acrocephalus schoenobaenus). Behaviour 59:226-246.

DAwINS, R. 1976. Hierarchical organisation: a candidate principle for ethology, p. 7-54. In P. P. G. Bateson and R. A. Hinde [EDS.], Growing points in ethology. Cambridge University Press, Cambridge, UK.

Dobson, C. W., And R. E. Lemon. 1979. Markov sequences in songs of American thrushes. Behaviour 68:86-105.

FARABAUGH, S. M. 1982. The ecological and social significance of duetting, p. 85-124. In D. E. Kroodsma and E. H. Miller [EDS.], Acoustic communication in birds. Vol. 2. Song learning and its consequences. Academic Press, New York.

Ficken, M. S., E. D. Hailman, and J. P. Hailman. 1994. The chick-a-dee call system of the Mexican Chickadee. Condor 96:70-82.

Ficken, M. S., AND J. W. PopP. 1992. Syntactical organization of the gargle vocalization of the Blackcapped Chickadee, Parus atricapillus. Ethology 91:156-168.

Ficken, M. S., K. R. Rusch, S. J. TAylor, AND D. R. POWERS. 2000. Blue-throated Hummingbird song: a pinnacle of nonoscine vocalizations. Auk 117: 120-128.

Fitch, W. T., AND M. D. HAUSER. 2004. Computational constraints on syntactic processing in a nonhuman primate. Science 303:377-380.

GIL, D., AND P. J. B. Slater. 2000. Song organisation and singing patterns of the Willow Warbler, Phylloscopus trochilus. Behaviour 137:759-782.

HaILman, J. P. 1989. The organization of major vocalizations in the Paridae. Wilson Bulletin 101:305343.

Hailman, J. P., AND M. S. Ficken. 1986. Combinatorial animal communication with computable syntax: chick-a-dee calling qualifies as 'language' by structural linguistics. Animal Behaviour 34:18991901.

Howes-Jones, D. 1985. The complex song of the Warbling Vireo. Canadian Journal of Zoology 63: 2756-2766.

IsAAC, D., AND P. MARLER. 1963. Ordering of sequences of singing behaviour of Mistle Thrushes in relationship to timing. Animal Behaviour 11:179188.

ISLER, M. L., P. R. ISLER, AND B. M. WhitNey. 1998. Use of vocalizations to establish species limits in antbirds (Passeriformes: Thamnophilidae). Auk 115:577-590.

Kroodsma, D. E. 1980. Winter Wren singing behavior: a pinnacle of song complexity. Condor 82:357365.

Kroodsma, D. E. 1984. Songs of the Alder Flycatcher (Empidonax alnorum) and Willow Flycatcher (Empidonax traillii) are innate. Auk 101:13-24.

Kroodsma, D. E. 1985. Development and use of two song forms by the Eastern Phoebe. Wilson Bulletin 97:21-29. 
Kroodsma, D. E., And M. Konishi. 1991. A suboscine bird (Eastern Phoebe, Sayornis phoebe) develops normal song without auditory feedback. Animal Behaviour 42:477-487.

Kroodsma, D. E., V. A. Ingalls, T. W. Sherry, and T. K. Werner. 1987. Songs of the Cocos Flycatcher: vocal behavior of a suboscine on an isolated oceanic island. Condor 89:75-84.

Leger, D. W., K. E. Brooks, and J. O'Brien. 2000. Versatility from a single song: the case of the Nightingale Wren. Auk 117:1038-1042.

LEGER, D. W., AND D. J. MounTJOy. 2003. Geographic variation in song of the Bright-rumped Attila (Tyrannidae: Attila spadiceus): implications for species status. Auk 120:69-74.

Lemon, R. E., and C. Chatfield. 1973. Organization of song of Rose-breasted Grosbeaks. Animal Behaviour 21:28-44.

Lovell, S. F., AND M. R. LeIN. 2004. Song variation in a population of Alder Flycatchers. Journal of Field Ornithology 75:146-151.

Morse, D. H. 1989. Song patterns of warblers at dawn and dusk. Wilson Bulletin 101:26-35.

Morton, E. S. 1996. A comparison of vocal behavior among tropical and temperate passerine birds, $\mathrm{p}$. 258-268. In D. E. Kroodsma and E. H. Millers [EDS.], Ecology and evolution of acoustic communication in birds. Cornell University Press, Ithaca, NY.

Nowicki, S., AND J. Podos. 1993. Complexity, coupling, and contingency in the production of birdsong, p. 159-186. In P. P. G. Bateson, P. H. Klopfer, and N. S. Thompson [EDS.], Perspectives in ethology. Vol. 10. Plenum Press, New York.

PARKER, T. A., III. 1984. Notes on the behavior of Ramphotrigon flycatchers. Auk 101:186-188.

PAyne, R. B., AND P. Budde. 1979. Song differences and map distances in a population of Acadian Flycatchers. Wilson Bulletin 91:29-41.

RAPPOLE, J. H. 1995. The ecology of migrant birds: a Neotropical perspective. Smithsonian Institution Press, Washington, DC.

Sibley, C. G., And B. L. Monroe JR. 1990. Distribution and taxonomy of birds of the world. Yale University Press, New Haven, CT.

SKuTCH, A. F. 1971. Life history of the Bright-rumped Attila Attila spadiceus. Ibis 113:316-322.

Slater, P. J. B., R. F. LAChlan, AND K. Riebel. 2000. The significance of learning in signal development: the curious case of the Chaffinch, p. 341352. In Y. Espmark, T. Amundsen, and G. Rosenqvist [EDS.], Animal signals: signalling and sig- nal design in animal communication. Tapir Academic Press, Trondheim, Norway.

Slater, P. J. B., And N. I. Mann. 2004. Why do the females of many bird species sing in the tropics? Journal of Avian Biology 35:289-294.

Smith, W. J. 1966. Communication and relationships in the genus Tyrannus. Publications of the Nuttall Ornithological Club 6:1-250.

SмIтH, W. J. 1970. Song-like displays in Sayornis species. Behaviour 37:64-84.

Smith, W. J. 1988. Patterned daytime singing of the Eastern Wood-pewee, Contopus virens. Animal Behaviour 36:1111-1123.

Smith, W. J., AND A. M. Smith. 1996. Vocal signaling of the Great Crested Flycatcher, Myiarchus crinitus (Aves, Tyrannidae). Ethology 102:705-723.

SNow, B. 1977. Territorial behavior and courtship of the male Three-wattled Bellbird. Auk 94:623645.

StAICER, C. A. 1989. Characteristics, use, and significance of two singing behaviors in Grace's Warbler (Dendroica graciae). Auk 106:49-63.

Staicer, C. A., D. A. Spector, And A. G. Horn. 1996. The dawn chorus and other diel patterns in acoustic signaling, p. 426-453. In D. E. Kroodsma and E. H. Miller [EDS.], Ecology and evolution of acoustic communication in birds. Cornell University Press, Ithaca, New York.

Stutchbury, B. J. M., and E. S. Morton. 2001. Behavioral ecology of tropical birds. Academic Press, San Diego, CA.

Todt, D., AND H. Hultsch. 1998. Hierarchical learning, development and representation of song, $\mathrm{p}$. 275-303. In R. Balda, I. Pepperberg, and A. Kamil [EDS.], Animal cognition in nature. Academic Press, San Diego, CA.

WiLEY, R. H. 2005. Individuality in songs of Acadian Flycatchers and recognition of neighbours. Animal Behaviour 70:237-247.

ZANN, R. 1993. Structure, sequence and evolution of song elements in wild Australian Zebra Finches. Auk 110:702-715.

ZIMMER, K. J. 1999. Behavior and vocalizations of the Caura and the Yapacana Antbirds. Wilson Bulletin 111:195-209.

Zimmer, K. J., AND A. Whittaker. 2000. Species limits in Pale-tipped Tyrannulets (Inezia: Tyrannidae). Wilson Bulletin 112:51-66.

Zimmer, K. J., A. Whittaker, AND D. C. Oren. 2001. A cryptic new species of flycatcher (Tyrannidae: Suiriri) from the cerrado region of central South America. Auk 118:56-78. 